\title{
Stress Induces Pain Transition by Potentiation of AMPA Receptor Phosphorylation
}

\author{
Changsheng Li, ${ }^{1,5 *}$ Ya Yang, ${ }^{1,2 *}$ (D) Sufang Liu, ${ }^{1,5 *}$ Huaqiang Fang, ${ }^{3}$ Yong Zhang, ${ }^{1}$ Orion Furmanski, ${ }^{1}$ John Skinner, ${ }^{1}$ \\ Ying Xing, ${ }^{5,6}$ Roger A. Johns, ${ }^{1}$ Richard L. Huganir, ${ }^{3,4}$ and ${ }^{\odot}$ Feng Tao ${ }^{1,7}$ \\ ${ }^{1}$ Department of Anesthesiology and Critical Care Medicine, ${ }^{2}$ The Russell H. Morgan Department of Radiology and Radiological Science, ${ }^{3}$ Solomon H. \\ Snyder Department of Neuroscience, and ${ }^{4}$ Howard Hughes Medical Institute, Johns Hopkins University School of Medicine, Baltimore, Maryland 21205, \\ ${ }^{5}$ Basic Medical College, Zhengzhou University, Zhengzhou, Henan 450001, People’s Republic of China, ${ }^{6}$ Basic Medical College, Xinxiang Medical University, \\ Xinxiang, Henan 453003, People's Republic of China, and 7Department of Biomedical Sciences, Texas A\&M University Baylor College of Dentistry, Dallas, \\ Texas 75246
}

Chronic postsurgical pain is a serious issue in clinical practice. After surgery, patients experience ongoing pain or become sensitive to incident, normally nonpainful stimulation. The intensity and duration of postsurgical pain vary. However, it is unclear how the transition from acute to chronic pain occurs. Here we showed that social defeat stress enhanced plantar incision-induced AMPA receptor GluA1 phosphorylation at the Ser831 site in the spinal cord and greatly prolonged plantar incision-induced pain. Interestingly, targeted mutation of the GluA1 phosphorylation site Ser831 significantly inhibited stress-induced prolongation of incisional pain. In addition, stress hormones enhanced GluA1 phosphorylation and AMPA receptor-mediated electrical activity in the spinal cord. Subthreshold stimulation induced spinal long-term potentiation in GluA1 phosphomimetic mutant mice, but not in wild-type mice. Therefore, spinal AMPA receptor phosphorylation contributes to the mechanisms underlying stress-induced pain transition.

Key words: AMPA receptor phosphorylation; pain transition; stress

\section{Introduction}

Pain is a hallmark of tissue damage and inflammation, which promotes tissue protection and thereby contributes to repair. Thus, transient acute pain is an important feature of the adaptive response to damage. However, pain can persist for months or years after surgery even though the surgical incision that originally caused the pain has healed. Such chronic pain is maladaptive because it no longer serves as a protective reaction. To date, the neurobiological mechanisms that underlie the transition from adaptive acute pain to maladaptive chronic pain are not fully understood (Mifflin and Kerr, 2014).

Previous studies have shown that psychosocial and socioenvironmental factors contribute to the development of chronic postsurgical pain (Kehlet et al., 2006; Katz and Seltzer, 2009). Psychosocial stress is generally defined as any conditions that disturb the physiological or psychological homeostasis of an or-

\footnotetext{
Received May 26, 2014; revised Aug. 28, 2014; accepted Sept. 3, 2014

Author contributions: R.L.H. and F.T. designed research; C.L., Y.Y., S.L., and F.T. performed research; C.L., Y.Y., S.L., H.F., Y.Z., O.F., J.S., Y.X., R.A.J., R.L.H., and F.T. analyzed data; R.L.H. and F.T. wrote the paper.

This work was supported by the National Institute of Dental and Craniofacial Research R01 Grant DE022880 (F.T. and R.L.H.) and the Blaustein Pain Research Fund (F.T.).

${ }^{*}$ C.L., Y.Y., and S.L. contributed equally to this work.

The authors declare no competing financial interests.

Correspondence should be addressed to either of the following: Dr. Feng Tao, 3302 Gaston Avenue, Dallas, TX 75246, E-mail:ta0@bcd.tamhsc.edu; or Dr. Richard L. Huganir, 725 North Wolfe Street, Hunterian 1009A, Baltimore, MD 21205, E-mail: rhuganir@jhmi.edu.

Dr. Li's present address: Affiliated Anti-cancer Hospital at Zhengzhou University, Zhengzhou, Henan 450001, People's Republic of China.

DOI:10.1523/JNEUROSCI.2130-14.2014

Copyright $\odot 2014$ the authors $\quad 0270-6474 / 14 / 3413737-10 \$ 15.00 / 0$
}

ganism (Kim and Diamond, 2002; Krugers et al., 2010). Exposure to stressful events induces physiological and behavioral changes that promote long-term adaptive responses to such disturbances (Krugers et al., 2010). One of the core reactions in response to a stressful event is the rapid activation of the autonomic nervous system and subsequent release of epinephrine and norepinephrine (NE) into the circulation (de Kloet et al., 2005). NE can activate cAMP-dependent protein kinase A (PKA) and calcium/ calmodulin-dependent protein kinase II (CaMKII; Hall, 2004; Wang et al., 2004b). AMPA receptor GluA1 Ser831 is phosphorylated by CaMKII and PKC, whereas GluA1 Ser845 is phosphorylated by PKA (Roche et al., 1996; Barria et al., 1997; Mammen et al., 1997). Genetically modified mice with knock-in mutations that block phosphorylation at the Ser831 and Ser845 sites of GluA1 show disturbances in synaptic plasticity and learning (Lee et al., 2003). Thus, the stress hormone NE can induce GluA1 phosphorylation at Ser831 and Ser845 sites, and thereby facilitate long-term potentiation (LTP) induction (Hu et al., 2007). Phosphorylation at these sites is necessary and sufficient to lower the threshold for GluA1 synaptic incorporation during LTP ( $\mathrm{Hu}$ et al., 2007). In addition, stressful events stimulate the hypothalamus-pituitary-adrenal axis, and glucocorticoids, a type of corticosteroid hormone, are released from the adrenal glands after exposure to a stressful event (de Kloet et al., 2005). Corticosterone (Cort) is the main glucocorticoid in rodents, and can rapidly and persistently regulate AMPA receptor GluA2 trafficking, which is crucially involved in synaptic transmission and plasticity (Groc et al., 2008; Krugers et al., 2010). Glucocorticoid receptors 
have been located in the spinal cord dorsal horn neurons (Cintra et al., 1993). It has been reported (Wang et al., 2004a) that glucocorticoid receptors are increased primarily within superficial laminas of the ipsilateral spinal cord dorsal horn after peripheral nerve injury. Through activation of glucocorticoid receptors, the stress hormone Cort can effectively condition the synaptic content of AMPA receptors and then trigger synaptic potentiation (Groc et al., 2008; Krugers et al., 2010). In this study, we combined plantar incision with social defeat stress to investigate the pain transition process.

\section{Materials and Methods}

Mice. Male wild-type (WT), AMPA receptor GluA1 S831A-phosphodeficient mutant, and GluA1 S831D+S845D (DD) phosphomimetic mutant mice ( $8-10$ weeks old) with C57BL/6 genetic background were used in this study. Mice were housed under standard conditions with a $12 \mathrm{~h}$ light/dark cycle, were allowed food and water ad libitum, and acclimated in our animal facility for a minimum of 1 week before use in experiments. All animal experiments were performed with the approval of the Animal Care and Use Committee at Johns Hopkins University. All efforts were made to minimize animal suffering and to reduce the number of animals used.

Plantar incision. A plantar incision was performed in mice as described previously (Pogatzki and Raja, 2003). In brief, mice were anesthetized with $1.5-2 \%$ isoflurane. After antiseptic preparation of the left hindpaw, a 5 $\mathrm{mm}$ longitudinal incision was made through the skin and fascia of the plantar foot. The incision was started $2 \mathrm{~mm}$ from the proximal edge of the heel and extended toward the toes. The underlying muscle was elevated with a curved forceps, leaving the muscle origin and insertion intact.

Social defeat stress. A social defeat stress was performed as described previously (Tsankova et al., 2006; Covington et al., 2011; Wilkinson et al., 2011). In brief, CD1 mice were used to defeat C57BL/6 mice. The C57BL/6 mice were defeated for $10 \mathrm{~min} / \mathrm{d}$ and then housed for the remainder of the day with the CD1 aggressor but separated by a Plexiglas screen. This process was repeated daily for 10 consecutive days with a different CD1 aggressor each day. There was no any physical damage to the C57BL/6 mice during the stress session.

Mechanical pain behavioral testing. Pain behavioral testing was conducted by an investigator blinded to treatment groups, as described previously (Pogatzki and Raja, 2003) with minor modification. Mice were placed on an elevated wire mesh floor and were covered with a clear Plexiglas chamber. After acclimation for $30 \mathrm{~min}$, paw withdrawal responses to mechanical stimuli were determined using calibrated von Frey filaments $(0.08,0.15,0.25,0.41,0.75,1.2$, and $2.0 \mathrm{~g})$. Each monofilament was applied five times to the plantar side of the hindpaws for $\sim 1 \mathrm{~s}$ with a 10 s interval, starting with a force of $0.08 \times g$ and continuing in ascending order. A stimulus-related withdrawal was considered a positive response. The paw withdrawal threshold was calculated as the force at which the positive response occurred in three of five stimuli.

Western blotting. The mice were killed, and ipsilateral lumbar spinal cord tissues were harvested at $48 \mathrm{~h}$ after the incision was made. AMPA receptor phosphorylation in the spinal cord was analyzed with quantitative Western blotting. Membrane-bound proteins from the lumbar enlargement segments of mouse spinal cord were extracted as previously described (Tao et al., 2006). The affinity-purified anti-GluAl and antiphospho-GluA1 at Ser831/845 antibodies were used to assess the expression of total (T) GluA1 and phosphorylated GluA1 at the Ser831 and Ser845 sites, respectively. The intensity of Western blots was quantified with densitometry. The signals of phospho-specific GluAl antibodies were normalized to total GluAl in phosphorylation analysis.

Surface biotinylation assay. Spinal slices were incubated for $45 \mathrm{~min}$ on ice with artificial CSF (ACSF) containing $1.5 \mathrm{mg} / \mathrm{ml}$ sulfo-NHS-LCbiotin (Pierce) and then rinsed in ACSF to quench the biotin reaction. Next, the slices were homogenized in modified RIPA buffer (1\% Triton X-100, 0.1\% SDS, 0.5\% deoxycholic acid, $50 \mathrm{~mm} \mathrm{NaPO}_{4}, 150 \mathrm{~mm} \mathrm{NaCl}$, $2 \mathrm{~mm} \mathrm{NaF}, 1 \mathrm{~mm}$ PMSF, $1 \mathrm{mg} / \mathrm{ml}$ leupeptin, and $10 \mathrm{~mm}$ sodium pyrophosphate). The homogenates were centrifuged at $1000 \times g$ for $10 \mathrm{~min}$ at $4^{\circ} \mathrm{C}$, and then the supernatant (total soluble fraction) was collected and centrifuged at $20,000 \times g$ for $20 \mathrm{~min}$ at $4^{\circ} \mathrm{C}$. The pellet $(\mathrm{P} 1$; crude plasma membrane fraction) was resolved in the RIPA buffer for use. After the measurement of protein concentration, $20 \%$ of $\mathrm{P} 1$ fraction was used for assessing total GluA1 expression. The remainder of the P1 fraction was incubated with $50 \%$ NeutrAvidin agarose (Pierce) for $4 \mathrm{~h}$ at $4^{\circ} \mathrm{C}$ and washed three times with RIPA buffer. T and biotinylated surface (S) proteins were assessed using quantitative Western blotting.

Cross-linking assay. The mice were killed, and transverse spinal dorsal horn slices $(450 \mu \mathrm{m})$ were prepared on day 7 after stress. Spinal slices were placed into ice-cold ACSF with or without $1 \mathrm{mg} / \mathrm{ml} \mathrm{BS}^{3}$ for $45 \mathrm{~min}$ at $4^{\circ} \mathrm{C} . \mathrm{BS}^{3}$ is a membrane-impermeable cross-linking reagent that crosslinks proteins only on the surface of cells (Grosshans et al., 2002a,b). Because $\mathrm{BS}^{3}$ is unable to enter polyacrylamide gels, the intracellular pool of receptors was measured directly. To quench the remaining $\mathrm{BS}^{3}$ activity, the slices were washed three times in cold ACSF containing $20 \mathrm{~mm}$ Tris, pH 7.6. Homogenization and subcellular fractionation were performed as described in the surface biotinylation assay. Equal amounts of $\mathrm{T}$ and $\mathrm{BS}^{3}$-treated proteins were assessed using quantitative Western blotting.

Electrophysiology. In our electrophysiological experiments, pyramidal projection neurons in the laminae II (substantia gelatinosa) of the spinal cord dorsal horn were chosen for recording under microscope. AMPA receptor-mediated miniature EPSCs (mEPSCs) were recorded in spinal slices. For mEPSC recording, spinal cord slices were preincubated for 30 min. Cort was washed in while we recorded after the preincubation. Totally spinal mEPSCs were recording for $10 \mathrm{~min}$, and the last $5 \mathrm{~min}$ of recording was used for statistical analysis. We observed that the effect of Cort occurred within $3 \mathrm{~min} ; 0.5 \mu \mathrm{M}$ tetrodotoxin was included in perfusion solution. mEPSCs were recorded at a holding potential of $-70 \mathrm{mV}$, at which NMDA receptors are presumably blocked by $\mathrm{Mg}^{2+}$ ions. The following mEPSC characteristics were determined: frequency, peak amplitude, and decay time. For spinal LTP induction experiments, the magnitude of LTP was the average of the last $5 \mathrm{~min}$ of the field EPSP (fEPSP) amplitude and was expressed as a percentage of the baseline fEPSP amplitude. Spinal LTP was induced with a subthreshold $10 \mathrm{~Hz}$ stimulation that was applied for $90 \mathrm{~s}$ (900 pulses in total). The size of potentiation in the last 5 min was quantified. Representative fEPSP traces at baseline and during the last $5 \mathrm{~min}$ were shown. In addition, $10 \mu \mathrm{M}$ NE was perfused for $10 \mathrm{~min}$ before the subthreshold stimulation in some LTP induction experiments.

Bicuculline $(10 \mu \mathrm{M})$ and strychnine $(1 \mu \mathrm{M})$ were added to the perfusion solution to block inhibitory synaptic transmission in all experiments. AMPA receptor-mediated synaptic responses were isolated by treatment with APV $(100 \mu \mathrm{M})$ and confirmed by blocking with GYKI 53655, a selective AMPA receptor antagonist.

ELISA. Mice were rapidly anesthetized by isoflurane, and blood samples were obtained by heart puncture (Orlando et al., 2008). Blood was collected in ice-chilled EDTA-coated vials containing $10 \mu \mathrm{l}$ of Trasylol and centrifuged at $5000 \times g$ for $5 \mathrm{~min}$ at $4^{\circ} \mathrm{C}$ to separate plasma from cellular components. The plasma samples were stored at $-80^{\circ} \mathrm{C}$ until use. Plasma NE and Cort values were measured using ELISA according to the manufacturer's instructions. All samples and standards were assayed in duplicate.

Statistics. Data are expressed as the mean \pm SEM. Comparisons among groups were performed by one-way and two-way ANOVA followed by the Student-Newman-Keuls method. Differences with $p<0.05$ were considered statistically significant.

\section{Results}

Stress-induced prolongation of incisional pain is dependent on AMPA receptor GluA1 phosphorylation

Incisional pain was induced by a plantar incision in the left hindpaw of WT mice, as described previously (Pogatzki and Raja, 2003). We observed that plantar incision alone decreased paw withdrawal threshold in the ipsilateral hindpaw of the WT mice, starting from day 1 after surgery (Fig. $1 A$ ). The incision-induced pain lasted for $\sim 7 \mathrm{~d}$, and the paw withdrawal threshold returned to baseline level on day 7 after surgery (Fig. 1A). To determine 
A

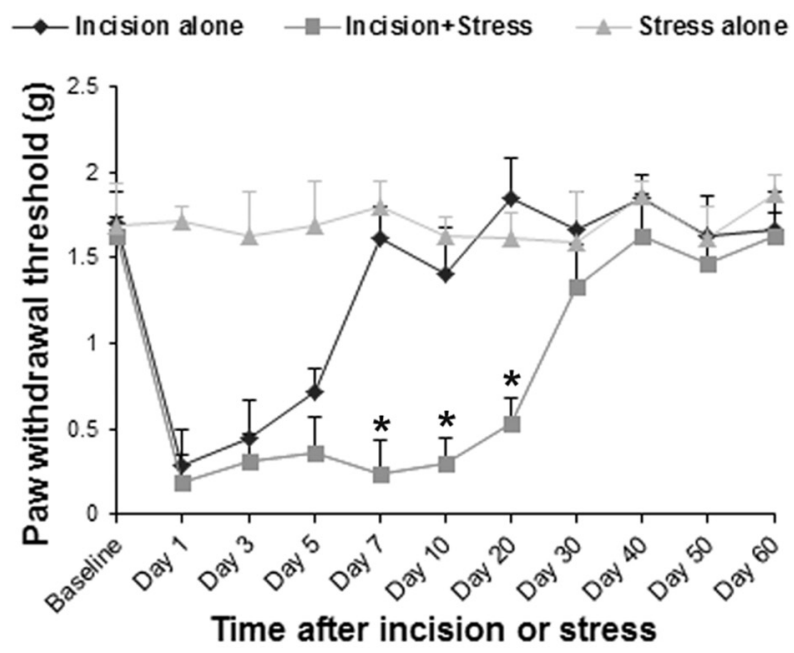

C

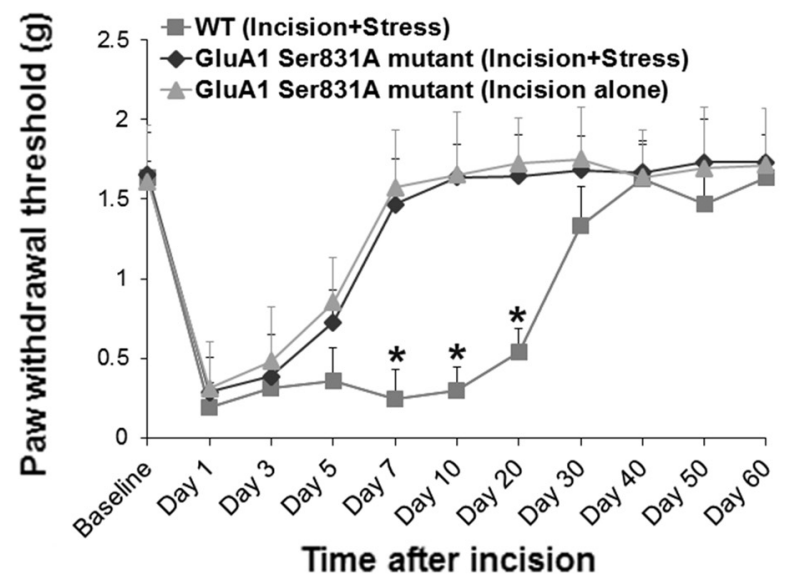

B Contralateral hindpaw

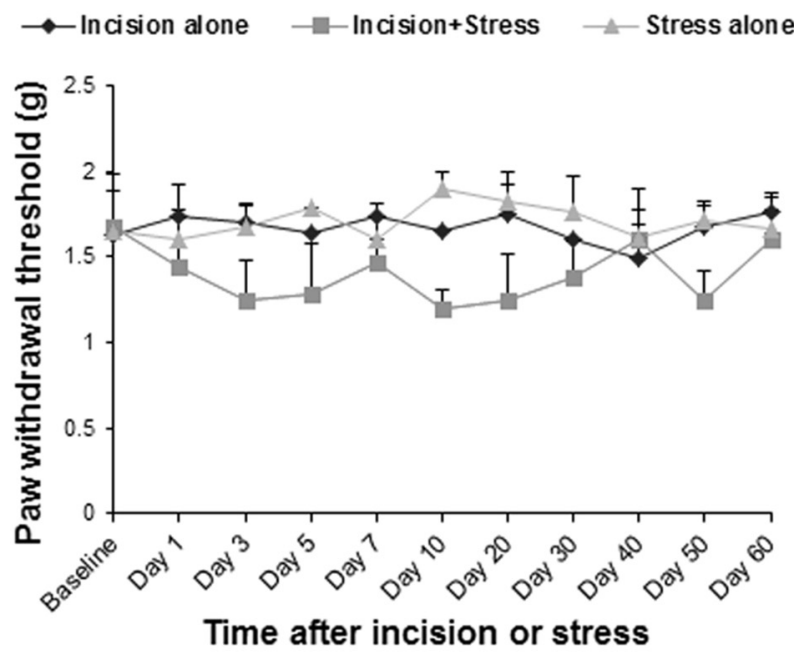

D

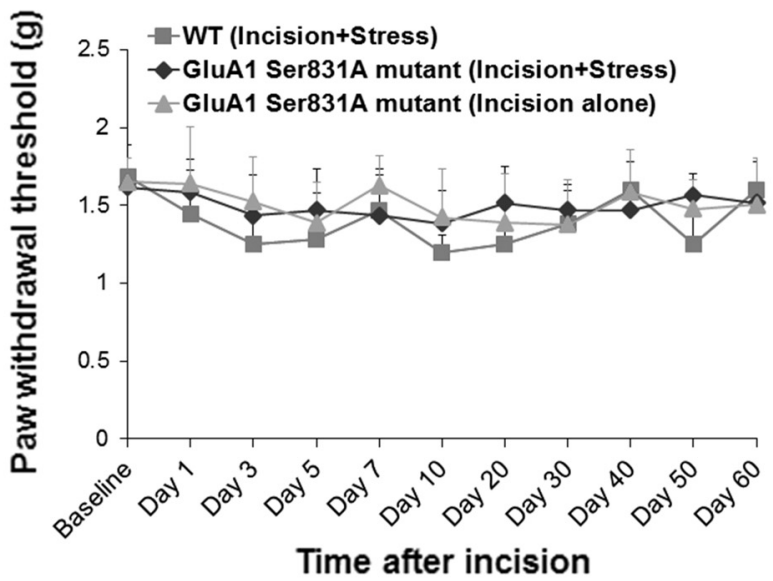

Figure 1. Targeted mutation of GluA1 phosphorylation at Ser831 in GluA1 Ser831A-phosphodeficient mutant mice significantly inhibits social defeat stress-induced prolongation of incisional pain. $\boldsymbol{A}$, Social defeat stress significantly prolonged the incision-induced pain in the ipsilateral hindpaw ( $n=10$ for each group; ${ }^{*} p<0.05$ vs incision-alone group). Social defeat stress alone $(n=9)$ did not produce pain behaviors. $\boldsymbol{B}$, All treatments had no effect on paw withdrawal threshold in the contralateral hindpaw. $\boldsymbol{C}$, Targeted mutation of GluA1 phosphorylation site Ser831 in the GluA1 S831A mutant mice significantly inhibited social defeat stress-induced prolongation of incisional pain in the ipsilateral hindpaw. There was no significant difference between the incision-alone and incision-plus-stress groups in the GluA1 S831A mutant mice ( $n=10$ for each group; ${ }^{*} p<0.05$ vs GluA1 S831A mutant mice). $D$, No pain behaviors were observed in the contralateral hindpaw of WT or GluA1 Ser831A mutant mice. The data from WT (incision-plus-stress) mice were used in $\boldsymbol{A}$ and $\boldsymbol{C}$ (ipsilateral hindpaw) as well as $\boldsymbol{B}$ and $\boldsymbol{D}$ (contralateral hindpaw).

whether stress can prolong the incisional pain and induce the transition from acute to chronic pain after surgery, mice were subjected to chronic social defeat stress before plantar incision based on published reports (Tsankova et al., 2006; Covington et al., 2011; Wilkinson et al., 2011). We found that social defeat stress significantly prolonged the incision-induced pain, and the paw withdrawal threshold in the ipsilateral hindpaw of the "incision-plus-stress" group did not return to baseline level until day 40 after surgery (Fig. $1 A,{ }^{\star} p<0.05$ vs incision-alone group). Neither incision alone nor incision plus stress had an effect on paw withdrawal threshold in the contralateral hindpaw (Fig. 1B). In addition, social defeat stress alone did not produce pain behaviors (Fig. 1A,B). To further investigate the importance of AMPA receptor phosphorylation in stress-induced prolongation of incisional pain, AMPA receptor GluA1 S831Aphosphodeficient mutant mice were used (Lee et al., 2003). In the mutant mice, GluA1 phosphorylation site Ser831 is mutated to alanine using a gene knock-in technique to prevent the phosphorylation of this site in vivo. Interestingly, we found that targeted mutation of the GluA1 phosphorylation site Ser831 in the GluA1 S831A mutant mice significantly inhibited social defeat stress-induced prolongation of incisional pain in the ipsilateral hindpaw (Fig. $1 C,{ }^{\star} p<0.05$ vs GluA1 S831A mutant mice). There was no significant difference between the incision-alone and incision-plus-stress groups in the GluA1 S831A mutant mice. These results indicate that AMPA receptor GluAl phosphorylation plays an important role in stress-induced prolongation of incisional pain. No pain behaviors were observed in the contralateral hindpaw of WT or GluA1 Ser831A mutant mice (Fig. 1D). The data from WT (incision-plus-stress) mice were used in Figure 1, $A$ and $C$ (ipsilateral hindpaw), as well as Figure $1, B$ and $D$ (contralateral hindpaw). 
A

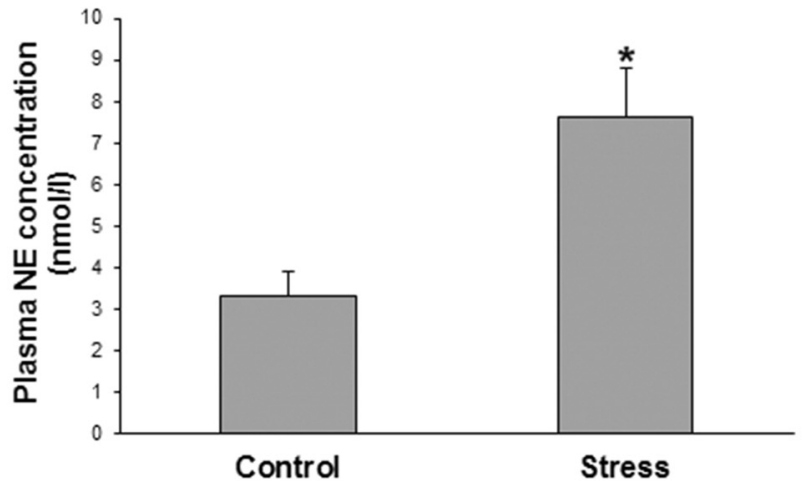

C

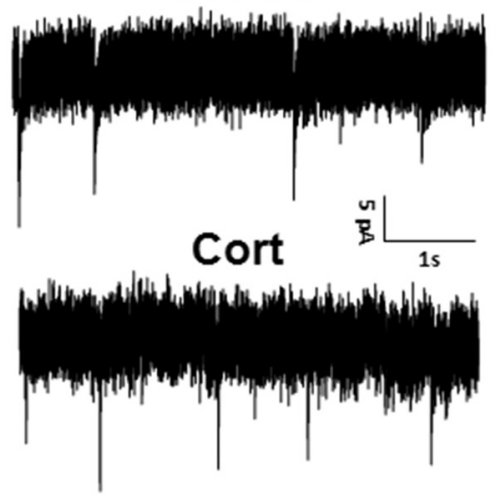

B

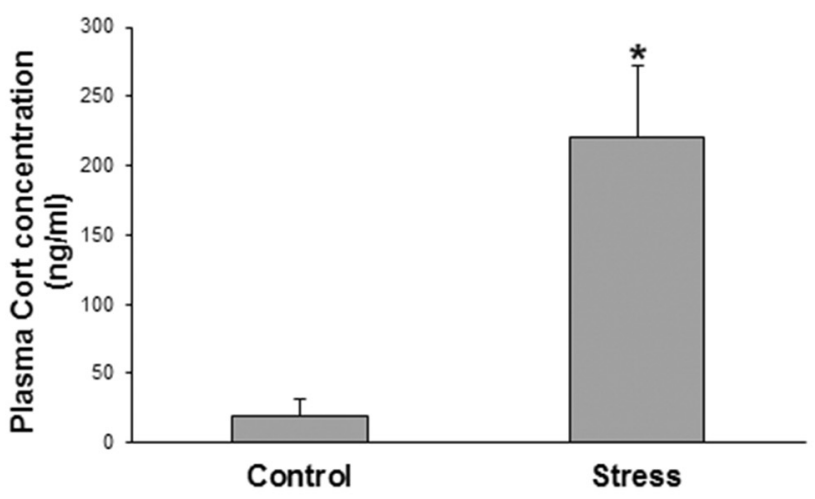

D

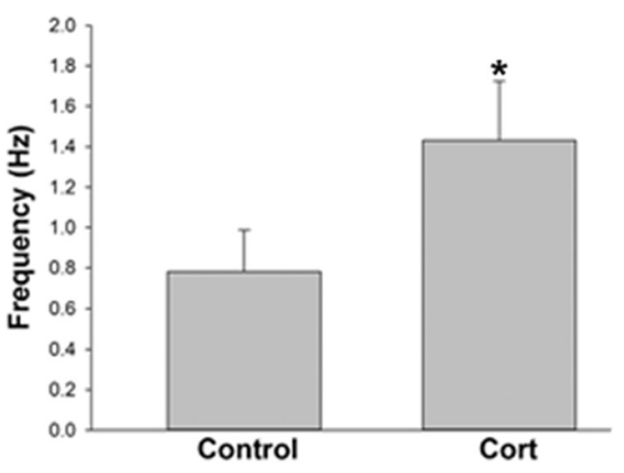

E

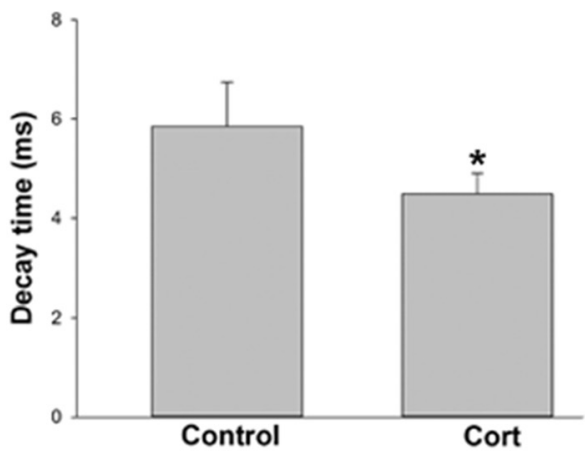

F

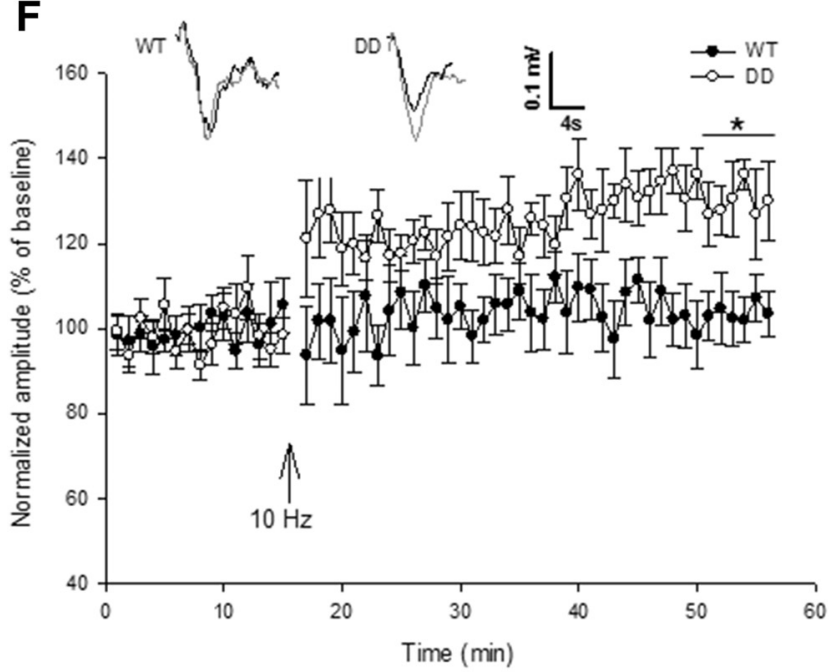

G

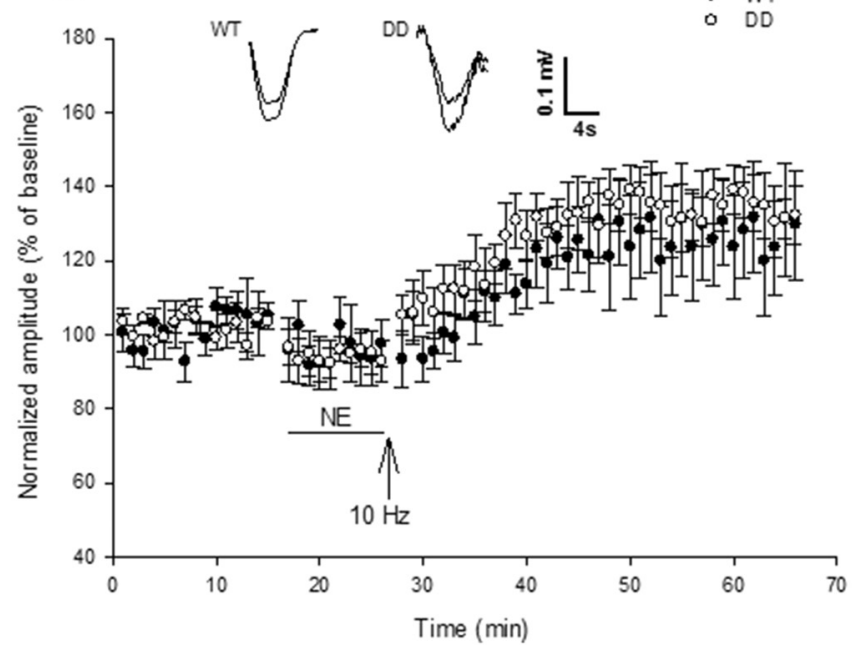

Figure 2. Stress hormones enhance AMPA receptor-mediated electrical activity and lower the threshold for LTP induction in the spinal dorsal horn neurons. $\boldsymbol{A}$, Social defeat stress significantly increased NE concentration in mouse plasma ( $n=6$ for each group; ${ }^{*} p<0.05$ vs control group). $\boldsymbol{B}$, Social defeat stress significantly increased Cort concentration in mouse plasma ( $n=6$ for each group; ${ }^{*} p<0.05$ vs control group). C, AMPA receptor-mediated mEPSCs were recorded in spinal slices. We observed that bath-applied Cort (100 nm) enhanced AMPA receptor-mediated electrical activity. $\boldsymbol{D}$, Cort significantly increased the mEPSC frequency ( $n=6$ slices and one slice per mouse; ${ }^{*} p<0.05$ vs control group). $\boldsymbol{E}$, Cort significantly decreased the decay time of the mEPSCs ( $n=$ 6 slices and one slice per mouse; ${ }^{*} p<0.05$ vs control group). $F$, Subthreshold $10 \mathrm{~Hz}$ stimulation induced spinal LTP in AMPA receptor GluA 1 DD phosphomimetic mutant mice, but not in WT mice. The size of potentiation in the last 5 min was quantified (WT mice: $103.9 \pm 0.9 \% ; n=7$ slices and one slice per mouse; $p>0.05$, vs baseline; DD mice: $130.2 \pm 1.6 \% ; n=6$ slices and one slice per mouse; $p<0.01$ vs baseline; ${ }^{*} p<0.05$ between WT and DD). G, Subthreshold stimulation following NE incubation (10 $\mu \mathrm{M}$ ) induced spinal LTP at similar levels in both WT and the GluA1 DD mutant mice. The size of potentiation in the last 5 min was quantified (WT mice: $127.2 \pm 2.3 \% ; n=6$ slices and one slice per mouse; $p<0.05$ vs baseline; DD mice: $132.9 \pm 1.0 \% ; n=5$ slices and one slice per mouse; $p<0.01$ vs baseline; $p>0.1$ between WT and DD). 
A

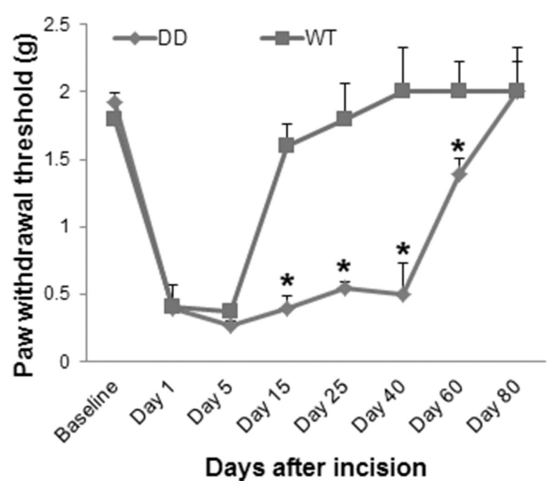

Figure 3. AMPA receptor GluA1 phosphorylation prolongs plantar incision-induced pain. $A$, Compared with WT mice, AMPA receptor GluA1 DD phosphomimetic mutant mice display prolonged pain behaviors in the ipsilateral hindpaw after plantar incision. Paw withdrawal thresholds in the DD mice do not return to baseline level until day 80 after the incision was made. $\boldsymbol{B}$, Plantar incision does not induce pain in the contralateral hindpaw of both the WT and DD mice.

\section{Stress hormones enhance AMPA receptor-mediated electrical activity and synaptic plasticity in the spinal dorsal horn neurons}

After the social defeat stress paradigm was repeated daily for 10 consecutive days, we measured plasma NE and Cort by using ELISA. Our data showed that the social defeat stress significantly increased the levels of NE and Cort in mouse plasma (Fig. 2A, $B$, ${ }^{\star} p<0.05$ vs control group). To reveal the effects of stress hormones on AMPA receptor-mediated electrical activity and synaptic plasticity in the spinal dorsal horn neurons, AMPA receptor-mediated mEPSCs and spinal LTP induction were recorded in the spinal cord slices prepared according to our previous study (Tao et al., 2003). It has been shown that Cort affects presynaptic release of glutamate and alters the frequency of hippocampal mEPSCs (Karst et al., 2005). In this study, we found that bath-applied Cort (100 nM) significantly increased the frequency of AMPA receptor-mediated mEPSCs in the spinal cord slices (Fig. $2 C, D,{ }^{\star} p<0.05$ vs control group), though it had no effect on the current peak amplitude. Cort perfusion also significantly decreased the decay time of the mEPSCs (Fig. $2 C, E,{ }^{\star} p<$ 0.05 vs control group). Our data suggest that spinal AMPA receptor-mediated electrical activity can be enhanced by the stress hormone Cort, and that Cort could affect the probability of presynaptic glutamate release, but may not influence number of postsynaptic AMPA receptors and glutamate vesicle size. Our results are consistent with a previous study (Karst et al., 2005) in acutely prepared adult mouse hippocampal slices, in which Cort enhances mEPSC frequency but has no effect on mEPSC amplitude (Karst et al., 2005). Furthermore, by using AMPA receptor GluA1 S831D+S845D phosphomimetic mutant mice (Makino et al., 2011), in which GluA1 phosphorylation sites Ser831 and Ser845 are mutated to aspartate using a gene knock-in technique to mimic the phosphorylation of these sites in vivo, we tested whether spinal LTP can be induced with a subthreshold $10 \mathrm{~Hz}$ stimulation. The percentage of fEPSP amplitude in the last $5 \mathrm{~min}$ of recording was compared with that at baseline. We found that the subthreshold $10 \mathrm{~Hz}$ stimulation induced spinal LTP in the AMPA receptor GluA1 DD phosphomimetic mutant mice, but not in WT mice (Fig. $2 F,{ }^{\star} p<0.05$ vs WT mice). In addition, NE can regulate AMPA receptor phosphorylation and then modify the possibility of synaptic plasticity (Hu et al., 2007). In this study, the subthreshold stimulation plus NE incubation induced spinal
LTP at similar levels in both WT and the GluA1 DD mutant mice (Fig. 2G). These results suggest that phosphorylation of GluA1 Ser831/Ser845 and NE treatment may reduce the threshold for spinal LTP induction, thereby potentiating synaptic plasticity in the spinal dorsal horn neurons. Recently, we conducted the plantar incision model in the DD mice and found that, compared with WT mice, the DD mice showed a prolonged incisional pain after plantar surgery (Fig. 3), which is similar to stress-induced pain prolongation in this model. Together, our data suggest that AMPA receptor phosphorylation plays an important role in stress-induced pain transition.

\section{Stress enhances spinal AMPA receptor GluA1 phosphorylation by releasing stress hormones}

To reveal whether stress affects incisional pain through regulating AMPA receptor activities in the spinal cord, we harvested ipsilateral lumbar spinal cord tissues at $48 \mathrm{~h}$ after incision. Western blot analysis showed that plantar incision significantly increased GluA1 phosphorylation at the Ser831 site (Fig. $4 A, B,{ }^{*} p<0.01$ vs sham control group) and that social defeat stress further enhanced plantar incision-induced GluA1 phosphorylation (Fig. $4 A, B, \# p<0.05$ vs incision group). Neither incision alone nor incision plus stress changed the expression of total GluAl (Fig. 4A,B). We also observed that plantar incision did not alter GluA1 phosphorylation at the Ser845 site, and that stress alone increased GluA1 phosphorylation at both Ser831 and Ser845 sites (Fig. $5)$. Moreover, to test whether stress hormones regulate AMPA receptor phosphorylation in the spinal cord, epinephrine $(0.5$ $\mathrm{mg} / \mathrm{kg}$, i.p.) was injected into WT mice, and lumbar spinal cord tissues were harvested $30 \mathrm{~min}$ after injection. Western blot analysis showed that systemic injection of epinephrine significantly increased GluA1 phosphorylation at the Ser831 site (Fig. $4 C, D,{ }^{* *} p<0.01$ vs saline control group), but did not affect total GluA1 level (Fig. $4 C, D$ ). In addition, the incubation with $10 \mu \mathrm{M}$ NE in the spinal cord slices time-dependently increased GluA1 Ser831 phosphorylation, but did not affect the expression of total GluA1 (Fig. 6). Together, our data suggest that stress may enhance spinal AMPA receptor GluA1 phosphorylation by releasing stress hormones. To further clarify the protein kinase dependence of NE-induced GluA1 phosphorylation in the spinal cord slices, we incubated the slices with $10 \mu \mathrm{M}$ NE and KN-93 $(20 \mu \mathrm{M})$, a CaMKII inhibitor, or KT5720 ( $4 \mu \mathrm{M})$, a PKA inhibitor, for $10 \mathrm{~min}$. We observed that the coincubation of NE with KN-93 inhibited the effect of NE on GluA1 Ser831 phosphorylation, but not Ser845 phosphorylation, and that the coincubation of NE with KT5720 inhibited the effect of NE on GluA1 Ser845 phosphorylation, but not Ser831 phosphorylation (Fig. 7). However, all of the treatments had no effect on the expression of total GluA1 (Fig. 7).

\section{Stress promotes synaptic AMPA receptor subunit switch in the spinal dorsal horn neurons}

To further investigate how AMPA receptor regulation is involved in stress-induced pain transition, we performed a surface biotinyla- 
tion assay and a cross-linking assay to examine spinal AMPA receptor membrane insertion and internalization, respectively. Transverse spinal dorsal horn slices $(450 \mu \mathrm{m})$ were prepared as described in our previous study (Tao et al., 2003) on day 7 after stress. In the surface biotinylation experiment, $\mathrm{T}$ and biotinylated $\mathrm{S}$ proteins were assessed using quantitative Western blotting. By calculating the surface GluA1/total GluA1 (S/T) ratio, we showed that stress significantly increased GluA1 membrane surface expression in the spinal dorsal horn neurons (Fig. $8 A, B,{ }^{\star} p<$ 0.05 vs control group). In the crosslinking experiment, equal amounts of $\mathrm{T}$ and $\mathrm{BS}^{3}$-treated proteins were assessed using quantitative Western blotting. By calculating the intracellular GluA2/total GluA2 $\left(\mathrm{BS}^{3} / \mathrm{T}\right)$ ratio, we showed that stress significantly increased GluA2 internalization in the spinal dorsal horn neurons (Fig. $8 C, D,{ }^{\star} p<0.05$ vs control group).

\section{Discussion}

The transition from acute to chronic postsurgical pain is a complex and poorly understood developmental process that involves biological, psychological, and socioenvironmental factors (Katz and Seltzer, 2009). Our study demonstrates that by releasing stress hormones, stress regulates AMPA receptor phosphorylation and trafficking, which leads to a change in synaptic AMPA receptor subunit composition and causes AMPA receptor subunit switch from $\mathrm{Ca}^{2+}$ impermeable (containing GluA2) to $\mathrm{Ca}^{2+}$ permeable (lacking GluA2). This switch will enhance $\mathrm{Ca}^{2+}$ influx and further activate $\mathrm{Ca}^{2+}$-dependent protein kinases, thereby promoting AMPA receptor phosphorylation and other phosphorylation-triggered activities. This positive feedback loop may contribute to the molecular mechanisms that underlie stress-induced pain transition after surgery. Previous studies have shown that a reduction in spinal $\mathrm{Ca}^{2+}$-permeable AMPA receptors is accompanied by a loss of nociceptive plasticity, whereas an increase in spinal $\mathrm{Ca}^{2+}$-permeable AMPA receptors facilitates nociceptive plasticity, and enhances spinal LTP and long-lasting inflammatory hyperalgesia (Hartmann et al., 2004; Youn et al., 2008), suggesting that AMPA receptors are not mere determinants of fast synaptic transmission underlying basal pain sensitivity, but are critically involved in activity-dependent changes in synaptic processing of nociceptive inputs.

After tissue injury or nerve damage, synaptic efficacy increases in somatosensory neurons in the dorsal horn of the spinal cord, a process called "central sensitization" (a specific form of synaptic plasticity). AMPA receptor phosphorylation and trafficking are critical for spinal central sensitization in response to nociceptive stimulation (Katano et al., 2008; Park et al., 2009). It is widely believed that long-lasting changes in spinal central sensitization (e.g., spinal LTP) serve as a neural basis of chronic pain development. The C-terminal domains of different AMPA receptor subunits have different phosphorylation sites (Malinow and Malenka, 2002; Song and Huganir, 2002; Bredt and Nicoll, 2003;
B

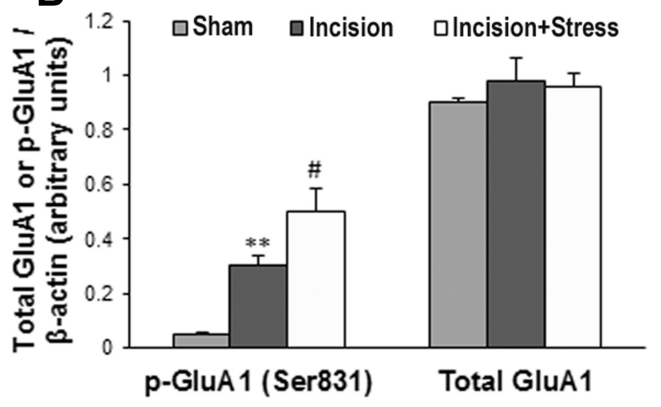

D

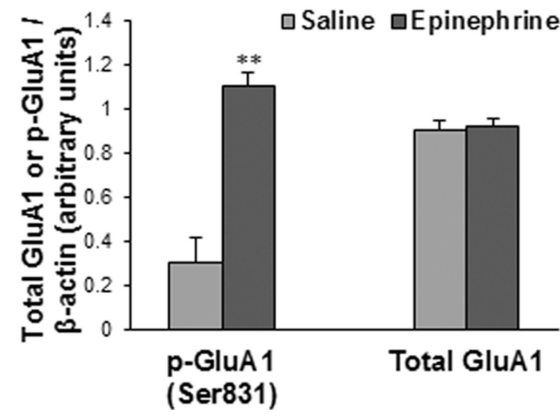

Figure 4. Stress enhances plantar incision-induced GluA1 phosphorylation at Ser831 and systemic injection of epinephrine inces

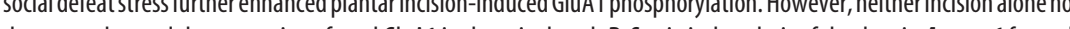
phosphorylation at the Ser831 site, but did not affect total GluA1 level in the spinal cord. D, Statistical analysis of the data in $\boldsymbol{C} . n=$ 6 for each group. ${ }^{* *} p<0.01$ vs saline control group. $\beta$-Actin served as a loading control in all Western blot experiments.

Shepherd and Huganir, 2007). This variation allows subunitspecific regulation of AMPA receptors during synaptic transmission and plasticity. It has been shown that the phosphorylation of GluA1 at Ser831 and Ser845 sites is sufficient to lower the threshold for LTP induction and increase the probability of synaptic plasticity (Makino et al., 2011) and that targeted mutation of the GluA2 phosphorylation site at Ser880 inhibits chronic inflammatory pain (Park et al., 2009). In the present study, we found that stress-induced prolongation of incisional pain is significantly inhibited in AMPA receptor GluA1 S831A-phosphodeficient mutant mice and that the subthreshold stimulation induces spinal LTP in GluA1 DD phosphomimetic mutant mice, suggesting that GluA1 phosphorylation at S831 site is involved in stress-induced pain transition and that the GluA1 phosphorylation is sufficient to reduce the threshold for spinal LTP induction. The DD mutant mice are altered at both the Ser831 and Ser845 sites (Makino et al., 2011). It would be interesting to determine whether the phosphorylation of Ser831, Ser845, or either of them is necessary for stress-regulated spinal central sensitization. In addition, we also found that the subthreshold stimulation plus NE incubation induce spinal LTP at a similar level in both the WT and the GluA1 DD mutant mice, suggesting that the subthreshold stimulation-induced spinal LTP in the GluA1 DD mutant mice is attributed to the phosphomimicry of GluA1 S831 and S845 but not to nonspecific changes in the mutant mice. Therefore, stress-produced regulation of AMPA receptor phosphorylation may be critical for spinal central sensitization and stress-induced pain transition.

NE plays important roles in the CNS through the activation of different adrenergic receptors ( $\alpha$ - and $\beta$-adrenoceptors). It has been reported (Stone et al., 1997; Baba et al., 2000a,b; Kawasaki et 
A

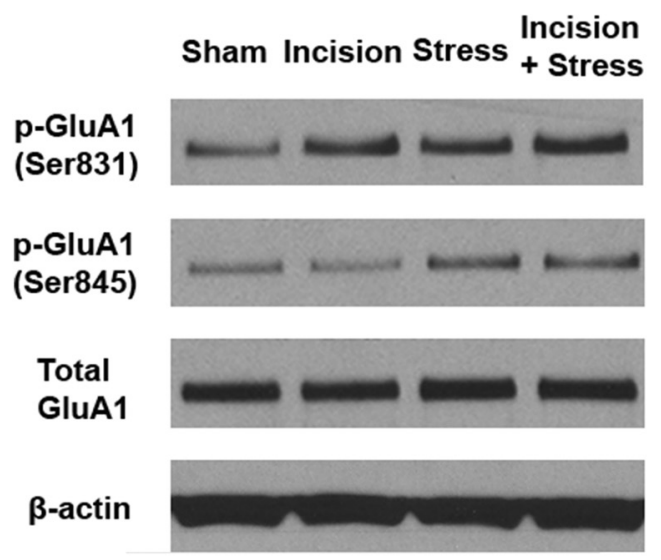

B

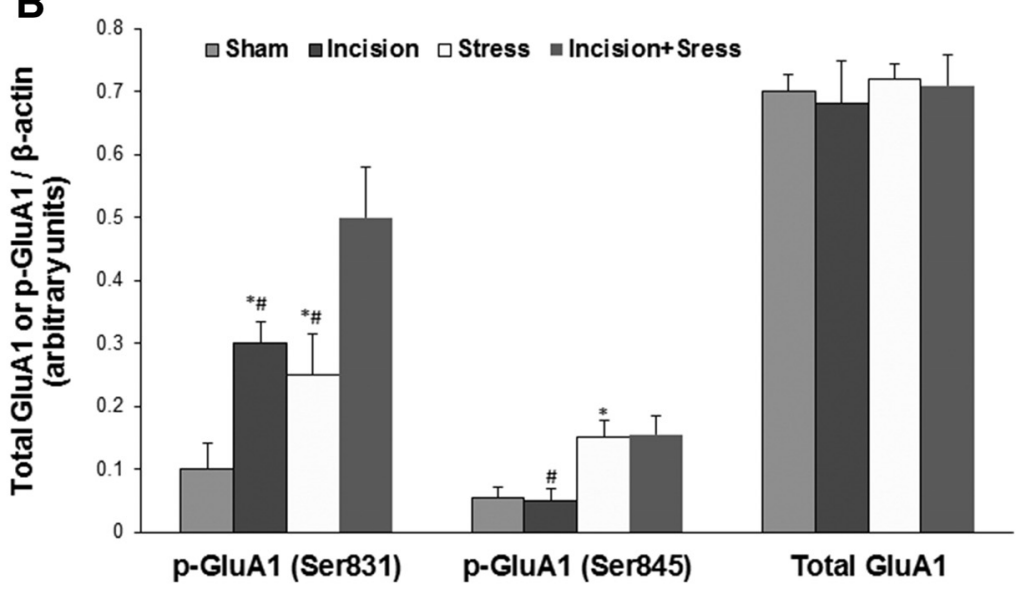

Figure 5. Effect of incision and/or stress on GluA1 phosphorylation at Ser831 and Ser845 sites in the spinal cord. A, Plantar incision increased GluA1 Ser831 phosphorylation, but not Ser845 phosphorylation; social defeat stress increased GluA1 phosphorylation at both the Ser831 and Ser845 sites; incision plus stress further enhanced incision-induced GluA1 Ser831 phosphorylation. However, neither incision/stress alone nor incision plus stress changed the expression of total GluA1 in the spinal cord. $B$, Statistical analysis of the data in $A . n=5$ for each group. ${ }^{*} p<0.05$ vs the sham control group; $\# p<0.05$ vs the incision plus stress group. $\beta$-Actin served as a loading control in all Western blot experiments.

A

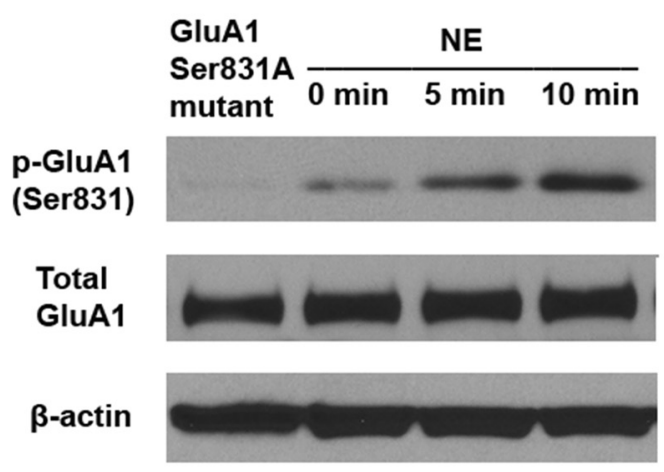

B

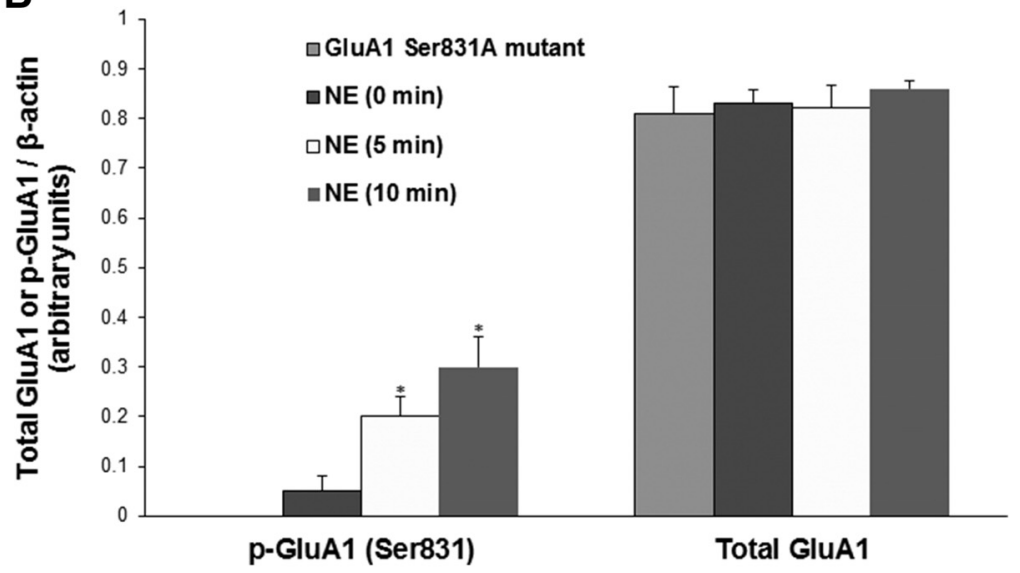

Figure 6. Effect of NE incubation on GluA1 phosphorylation at Ser831 site in spinal cord slices. $A$, The incubation with $10 \mu \mathrm{m}$ NE time-dependently increased GluA1 Ser831 phosphorylation, but did not affect the expression of total GluA1. The slices from GluA1 Ser831A mutant mice were used as a negative control for the GluA1 Ser831 phosphorylation. $\boldsymbol{B}$, Statistical analysis of the data in A. $n=5$ for each group. ${ }^{*} p<0.05$ vs the control group [NE $(0 \mathrm{~min})$ ]. $\beta$-Actin served as a loading control in all Western blot experiments.

al., 2003; Pertovaara, 2013) that NE is involved in intrinsic control of pain through action on $\alpha_{1}$ - and $\alpha_{2}$-adrenoceptors. In brief, $\mathrm{NE}$ attenuates pain by inhibitory action on $\alpha_{2 \mathrm{~A}}$-adrenoceptors on central terminals of primary afferent nociceptors, by direct $\alpha_{2}$ adrenergic action on spinal pain-relay neurons, and by $\alpha_{1^{-}}$ adrenergic activation of inhibitory interneurons. Meanwhile, it has been shown that NE enhances AMPA receptor phosphorylation through action on $\beta$-adrenoceptor (Vanhoose and Winder, 2003; Hu et al., 2007). Thus, the effect of noradrenergic system on pain transmission has varied depending on the action on the type of adrenoceptor.

In postoperative patients, secondary mechanical hyperalgesia and central sensitization after surgery have been reported (Richmond et al., 1993; Stubhaug et al., 1997). By using an antagonist to $\mathrm{Ca}^{2+}$-permeable AMPA receptors, it has been shown (Pogatzki et al., 2003) that the antagonist selectively reverses the secondary mechanical hyperalgesia and has no effect on primary mechanical hyperalgesia in the plantar incision model, indicating that central sensitization causing secondary hyperalgesia in postoperative patients is mediated by the activities of $\mathrm{Ca}^{2+}$-permeable AMPA receptors; however, primary hyperalgesia resulting from the incision is not dependent on these receptors. Therefore, a more specific agent (e.g., siRNA/shRNA of the receptor) could be used to specifically inhibit the secondary hyperalgesia following the incision and prevent the transition from acute to chronic pain after surgery.

Previous studies (Vitale et al., 2005; Hua et al., 2006; Hayati et al., 2008; Kumar and Goyal, 2008; Kumar et al., 2009; Botelho et al., 2010; Lafrance et al., 2010; Fechir et al., 2012; HeidariOranjaghi et al., 2012; Vachon-Presseau et al., 2013) have demonstrated that exposure to an acute and intense stress induces a reduction in pain sensation, which is called "stress-induced analgesia." The stress-induced analgesia is mediated by descending inhibitory pain modulation, and endogenous opioid, monoamine, cannabinoid, GABA, and glutamate systems play key roles in the modulation (Butler and Finn, 2009). On the other hand, considerable evidence (Andre et al., 2005; Bardin et al., 2009; Khasar et al., 2009; Dina et al., 2011; Le Roy et al., 2011; Quintero et al., 2011; Gibbons et al., 2012; Crettaz et al., 2013; Jennings et 


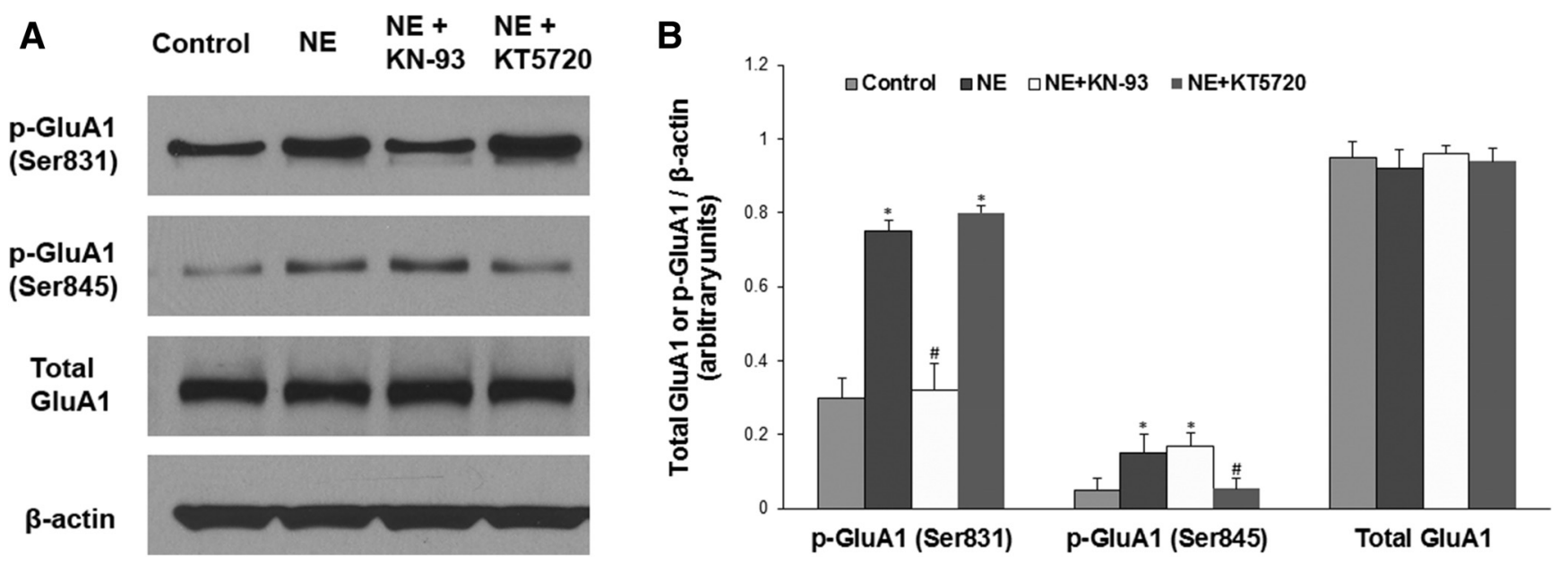

Figure 7. Protein kinase dependence of NE-induced GluA1 phosphorylation in spinal cord slices. $A$, The incubation with $10 \mu \mathrm{m} \mathrm{NE} \mathrm{for} 10$ min increased GluA1 phosphorylation at both the Ser831 and Ser845 sites; the coincubation of NE with KN-93 $(20 \mu \mathrm{M})$, a CaMKII inhibitor, inhibited the effect of NE on GluA1 Ser831 phosphorylation, but not on Ser845 phosphorylation; the coincubation of NE with KT5720 $(4 \mu \mathrm{M})$, a PKA inhibitor, inhibited the effect of NE on GluA1 Ser845 phosphorylation, but not on Ser831 phosphorylation. However, all of the treatments had no effect on the expression of total GluA1. B, Statistical analysis of the data in $\boldsymbol{A} . n=5$ for each group. ${ }^{*} p<0.05$ vs the control group; $\# p<0.05$ vs the NE alone group. $\beta$-Actin served as a loading control in all Western blot experiments.

al., 2014) has shown that repeated or chronic exposure to a physical or psychological stress usually results in pain enhancement, which is called "stressinduced hyperalgesia." In the present study, we used repeated social defeat stress to investigate its effect on pain transition and examine the underlying mechanisms.

In this study, we discover a new role of AMPA receptor phosphorylation and phosphorylation-triggered AMPA receptor regulation in stress-induced pain transition. Previous studies (Hu et al., 2007; Groc et al., 2008) have shown that stress hormones regulate AMPA receptor phosphorylation and trafficking, thereby influencing synaptic plasticity and potentiation. Based on these previous findings, we investigated the molecular mechanisms underlying stress-induced pain transition after surgery. We showed that AMPA receptor-mediated spinal LTP was induced by subthreshold $10 \mathrm{~Hz}$ stimulation in AMPA receptor GluA1 DD phosphomimetic mutant mice, but not in WT mice (Fig. $2 F$ ), suggesting that GluA1 phosphorylation could lower the threshold for spinal LTP induction, thereby accounting for the potentiation of the behavioral response to incision. We also showed that stress hormone NE increased spinal GluA1 phosphorylation (Fig. 6), and that the subthreshold stimulation plus NE incubation induced spinal LTP at similar levels in both WT and the GluA1 phosphomimetic mutant mice (Fig. 2G). These results further indicate that GluA1 phosphorylation plays an important role in spinal central sensitization and stress-induced pain transition. Thus, our data support our conclusion that stress-regulated AMPA receptor phosphorylation contributes to the mechanisms underlying stress-induced pain control in these assays.
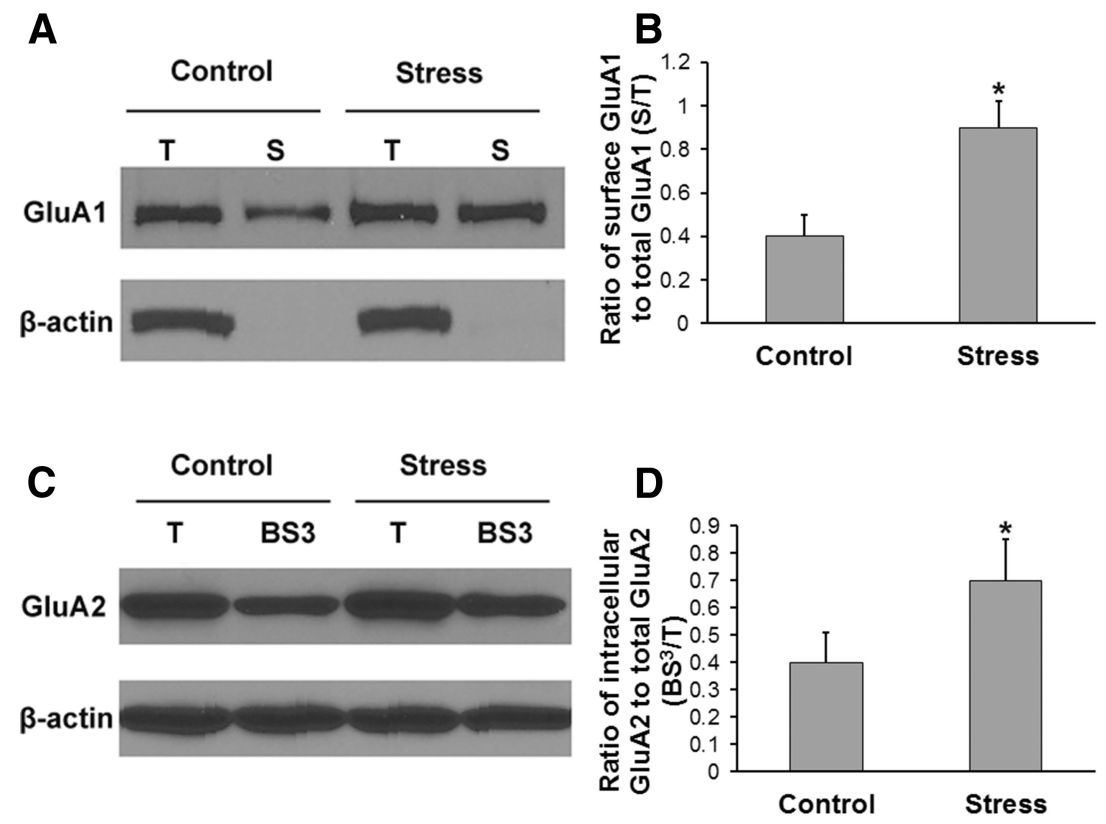

Figure 8. Stress increases GluA1 membrane insertion and GluA2 internalization in the spinal dorsal horn neurons. $A$, In the surface biotinylation experiment, T and biotinylated S proteins were assessed using quantitative Western blotting. $\boldsymbol{B}$, By calculating the surface $S / T$ ratio, we showed that stress significantly increased GluA1 membrane surface expression in the spinal dorsal horn neurons ( $n=6$ for each group; ${ }^{*} p<0.05$ vs control group). $C$, In the cross-linking experiment, equal amounts of $\mathrm{T}$ and $\mathrm{BS}^{3}$-treated $\left(\mathrm{BS}^{3}\right)$ proteins were assessed using quantitative Western blotting. $\boldsymbol{D}$, By calculating the intracellular $\mathrm{BS}^{3} / \mathrm{T}$ ratio, we showed that stress significantly increased GluA2 internalization in the spinal dorsal horn neurons ( $n=6$ for each group; ${ }^{*} p<0.05$ vs control group). $\beta$-Actin, an unbiotinylated intracellular protein, served as a

transition. In addition to enhancing AMPA receptor phosphorylation, stress may regulate other signaling pathways. The stress effect we described here must involve more than AMPA receptor phosphorylation. Our results identify stress as a risk factor for the development of chronic postsurgical pain. This finding will help us predict which patients are at greater risk for developing chronic pain after surgical procedures. Eventually, monitoring of stress hormone levels in the blood may help physicians improve pain control in high-risk patients. 


\section{References}

Andre J, Zeau B, Pohl M, Cesselin F, Benoliel JJ, Becker C (2005) Involvement of cholecystokininergic systems in anxiety-induced hyperalgesia in male rats: behavioral and biochemical studies. J Neurosci 25:7896-7904. CrossRef Medline

Baba H, Goldstein PA, Okamoto M, Kohno T, Ataka T, Yoshimura M, Shimoji K (2000a) Norepinephrine facilitates inhibitory transmission in substantia gelatinosa of adult rat spinal cord (part 2): effects on somatodendritic sites of GABAergic neurons. Anesthesiology 92:485-492. CrossRef Medline

Baba H, Shimoji K, Yoshimura M (2000b) Norepinephrine facilitates inhibitory transmission in substantia gelatinosa of adult rat spinal cord (part 1): effects on axon terminals of GABAergic and glycinergic neurons. Anesthesiology 92:473-484. CrossRef Medline

Bardin L, Malfetes N, Newman-Tancredi A, Depoortère R (2009) Chronic restraint stress induces mechanical and cold allodynia, and enhances inflammatory pain in rat: relevance to human stress-associated painful pathologies. Behav Brain Res 205:360-366. CrossRef Medline

Barria A, Muller D, Derkach V, Griffith LC, Soderling TR (1997) Regulatory phosphorylation of AMPA-type glutamate receptors by CaM-KII during long-term potentiation. Science 276:2042-2045. CrossRef Medline

Botelho AP, Gameiro GH, Tuma CE, Marcondes FK, de Arruda Veiga MC (2010) The effects of acute restraint stress on nociceptive responses evoked by the injection of formalin into the temporomandibular joint of female rats. Stress 13:269-275. CrossRef Medline

Bredt DS, Nicoll RA (2003) AMPA receptor trafficking at excitatory synapses. Neuron 40:361-379. CrossRef Medline

Butler RK, Finn DP (2009) Stress-induced analgesia. Prog Neurobiol 88: 184-202. CrossRef Medline

Cintra A, Molander C, Fuxe K (1993) Colocalization of Fos- and glucocorticoid receptor-immunoreactivities is present only in a very restricted population of dorsal horn neurons of the rat spinal cord after nociceptive stimulation. Brain Res 632:334-338. CrossRef Medline

Covington HE 3rd, Maze I, Sun H, Bomze HM, DeMaio KD, Wu EY, Dietz DM, Lobo MK, Ghose S, Mouzon E, Neve RL, Tamminga CA, Nestler EJ (2011) A role for repressive histone methylation in cocaine-induced vulnerability to stress. Neuron 71:656-670. CrossRef Medline

Crettaz B, Marziniak M, Willeke P, Young P, Hellhammer D, Stumpf A, Burgmer M (2013) Stress-induced allodynia-evidence of increased pain sensitivity in healthy humans and patients with chronic pain after experimentally induced psychosocial stress. PLoS One 8:e69460. CrossRef Medline

de Kloet ER, Joëls M, Holsboer F (2005) Stress and the brain: from adaptation to disease. Nat Rev Neurosci 6:463-475. CrossRef Medline

Dina OA, Levine JD, Green PG (2011) Enhanced cytokine-induced mechanical hyperalgesia in skeletal muscle produced by a novel mechanism in rats exposed to unpredictable sound stress. Eur J Pain 15:796-800. CrossRef Medline

Fechir M, Breimhorst M, Kritzmann S, Geber C, Schlereth T, Baier B, Birklein F (2012) Naloxone inhibits not only stress-induced analgesia but also sympathetic activation and baroreceptor-reflex sensitivity. Eur J Pain 16: 82-92. CrossRef Medline

Gibbons CH, Adler GK, Bonyhay I, Freeman R (2012) Experimental hypoglycemia is a human model of stress-induced hyperalgesia. Pain 153: 2204-2209. CrossRef Medline

Groc L, Choquet D, Chaouloff F (2008) The stress hormone corticosterone conditions AMPAR surface trafficking and synaptic potentiation. Nat Neurosci 11:868-870. CrossRef Medline

Grosshans DR, Clayton DA, Coultrap SJ, Browning MD (2002a) LTP leads to rapid surface expression of NMDA but not AMPA receptors in adult rat CA1. Nat Neurosci 5:27-33. CrossRef Medline

Grosshans DR, Clayton DA, Coultrap SJ, Browning MD (2002b) Analysis of glutamate receptor surface expression in acute hippocampal slices. Sci STKE 2002:pl8. CrossRef Medline

Hall RA (2004) Beta-adrenergic receptors and their interacting proteins. Semin Cell Dev Biol 15:281-288. CrossRef Medline

Hartmann B, Ahmadi S, Heppenstall PA, Lewin GR, Schott C, Borchardt T, Seeburg PH, Zeilhofer HU, Sprengel R, Kuner R (2004) The AMPA receptor subunits GluR-A and GluR-B reciprocally modulate spinal synaptic plasticity and inflammatory pain. Neuron 44:637-650. CrossRef Medline

Hayati AA, Zalina I, Myo T, Badariah AA, Azhar A, Idris L (2008) Modula- tion of formalin-induced fos-like immunoreactivity in the spinal cord by swim stress-induced analgesia, morphine and ketamine. Ger Med Sci 6:Doc05. Medline

Heidari-Oranjaghi N, Azhdari-Zarmehri H, Erami E, Haghparast A (2012) Antagonism of orexin-1 receptors attenuates swim- and restraint stressinduced antinociceptive behaviors in formalin test. Pharmacol Biochem Behav 103:299-307. CrossRef Medline

Hua S, Hermanussen S, Tang L, Monteith GR, Cabot PJ (2006) The neural cell adhesion molecule antibody blocks cold water swim stress-induced analgesia and cell adhesion between lymphocytes and cultured dorsal root ganglion neurons. Anesth Analg 103:1558-1564. CrossRef Medline

Hu H, Real E, Takamiya K, Kang MG, Ledoux J, Huganir RL, Malinow R (2007) Emotion enhances learning via norepinephrine regulation of AMPA-receptor trafficking. Cell 131:160-173. CrossRef Medline

Jennings EM, Okine BN, Roche M, Finn DP (2014) Stress-induced hyperalgesia. Prog Neurobiol. Advance online publication. Retrieved September 8, 2014. doi:10.1016/j.pneurobio.2014.06.003. CrossRef Medline

Karst H, Berger S, Turiault M, Tronche F, Schütz G, Joëls M (2005) Mineralocorticoid receptors are indispensable for nongenomic modulation of hippocampal glutamate transmission by corticosterone. Proc Natl Acad Sci U S A 102:19204-19207. CrossRef Medline

Katano T, Furue H, Okuda-Ashitaka E, Tagaya M, Watanabe M, Yoshimura M, Ito S (2008) N-ethylmaleimide-sensitive fusion protein (NSF) is involved in central sensitization in the spinal cord through GluR2 subunit composition switch after inflammation. Eur J Neurosci 27:3161-3170. CrossRef Medline

Katz J, Seltzer Z (2009) Transition from acute to chronic postsurgical pain: risk factors and protective factors. Expert Rev Neurother 9:723-744. CrossRef Medline

Kawasaki Y, Kumamoto E, Furue H, Yoshimura M (2003) Alpha 2 adrenoceptor-mediated presynaptic inhibition of primary afferent glutamatergic transmission in rat substantia gelatinosa neurons. Anesthesiology 98:682-689. CrossRef Medline

Kehlet H, Jensen TS, Woolf CJ (2006) Persistent postsurgical pain: risk factors and prevention. Lancet 367:1618-1625. CrossRef Medline

Khasar SG, Dina OA, Green PG, Levine JD (2009) Sound stress-induced long-term enhancement of mechanical hyperalgesia in rats is maintained by sympathoadrenal catecholamines. J Pain 10:1073-1077. CrossRef Medline

Kim JJ, Diamond DM (2002) The stressed hippocampus, synaptic plasticity and lost memories. Nat Rev Neurosci 3:453-462. CrossRef Medline

Krugers HJ, Hoogenraad CC, Groc L (2010) Stress hormones and AMPA receptor trafficking in synaptic plasticity and memory. Nat Rev Neurosci 11:675-681. CrossRef Medline

Kumar A, Goyal R (2008) Quercetin protects against acute immobilization stress-induced behaviors and biochemical alterations in mice. J Med Food 11:469-473. CrossRef Medline

Kumar A, Garg R, Gaur V, Kumar P (2009) Nitric oxide mechanism in protective effect of imipramine and venlafaxine against acute immobilization stress-induced behavioral and biochemical alteration in mice. Neurosci Lett 467:72-75. CrossRef Medline

Lafrance M, Roussy G, Belleville K, Maeno H, Beaudet N, Wada K, Sarret P (2010) Involvement of NTS2 receptors in stress-induced analgesia. Neuroscience 166:639-652. CrossRef Medline

Lee HK, Takamiya K, Han JS, Man H, Kim CH, Rumbaugh G, Yu S, Ding L, He C, Petralia RS, Wenthold RJ, Gallagher M, Huganir RL (2003) Phosphorylation of the AMPA receptor GluR1 subunit is required for synaptic plasticity and retention of spatial memory. Cell 112:631-643. CrossRef Medline

Le Roy C, Laboureyras E, Gavello-Baudy S, Chateauraynaud J, Laulin JP, Simonnet G (2011) Endogenous opioids released during nonnociceptive environmental stress induce latent pain sensitization Via a NMDA-dependent process. J Pain 12:1069-1079. CrossRef Medline

Makino Y, Johnson RC, Yu Y, Takamiya K, Huganir RL (2011) Enhanced synaptic plasticity in mice with phosphomimetic mutation of the GluAl AMPA receptor. Proc Natl Acad Sci U S A 108:8450-8455. CrossRef Medline

Malinow R, Malenka RC (2002) AMPA receptor trafficking and synaptic plasticity. Annu Rev Neurosci 25:103-126. CrossRef Medline

Mammen AL, Kameyama K, Roche KW, Huganir RL (1997) Phosphorylation of the alpha-amino-3-hydroxy-5-methylisoxazole4-propionic acid 
receptor GluR1 subunit by calcium/calmodulin-dependent kinase II. J Biol Chem 272:32528-32533. CrossRef Medline

Mifflin KA, Kerr BJ (2014) The transition from acute to chronic pain: understanding how different biological systems interact. Can J Anaesth 61: 112-122. CrossRef Medline

Orlando GF, Langnaese K, Schulz C, Wolf G, Engelmann M (2008) Neuronal nitric oxide synthase gene inactivation reduces the expression of vasopressin in the hypothalamic paraventricular nucleus and of catecholamine biosynthetic enzymes in the adrenal gland of the mouse. Stress 11:42-51. CrossRef Medline

Park JS, Voitenko N, Petralia RS, Guan X, Xu JT, Steinberg JP, Takamiya K, Sotnik A, Kopach O, Huganir RL, Tao YX (2009) Persistent inflammation induces GluR2 internalization via NMDA receptor-triggered PKC activation in dorsal horn neurons. J Neurosci 29:3206-3219. CrossRef Medline

Pertovaara A (2013) The noradrenergic pain regulation system: a potential target for pain therapy. Eur J Pharmacol 716:2-7. CrossRef Medline

Pogatzki EM, Raja SN (2003) A mouse model of incisional pain. Anesthesiology 99:1023-1027. CrossRef Medline

Pogatzki EM, Niemeier JS, Sorkin LS, Brennan TJ (2003) Spinal glutamate receptor antagonists differentiate primary and secondary mechanical hyperalgesia caused by incision. Pain 105:97-107. CrossRef Medline

Quintero L, Cardenas R, Suarez-Roca H (2011) Stress-induced hyperalgesia is associated with a reduced and delayed GABA inhibitory control that enhances post-synaptic NMDA receptor activation in the spinal cord. Pain 152:1909-1922. CrossRef Medline

Richmond CE, Bromley LM, Woolf CJ (1993) Preoperative morphine <\#> pre-empts postoperative pain. Lancet 342:73-75. CrossRef Medline

Roche KW, O’Brien RJ, Mammen AL, Bernhardt J, Huganir RL (1996) Characterization of multiple phosphorylation sites on the AMPA receptor GluR1 subunit. Neuron 16:1179-1188. CrossRef Medline

Shepherd JD, Huganir RL (2007) The cell biology of synaptic plasticity: AMPA receptor trafficking. Annu Rev Cell Dev Biol 23:613-643. CrossRef Medline

Song I, Huganir RL (2002) Regulation of AMPA receptors during synaptic plasticity. Trends Neurosci 25:578-588. CrossRef Medline

Stone LS, MacMillan LB, Kitto KF, Limbird LE, Wilcox GL (1997) The $\alpha 2$ a adrenergic receptor subtype mediates spinal analgesia evoked by $\alpha 2$ agonists and is necessary for spinal adrenergic-opioid synergy. J Neurosci 17:7157-7165. Medline

Stubhaug A, Breivik H, Eide PK, Kreunen M, Foss A (1997) Mapping of punctuate hyperalgesia around a surgical incision demonstrates that ket- amine is a powerful suppressor of central sensitization to pain following surgery. Acta Anaesthesiol Scand 41:1124-1132. CrossRef Medline

Tao F, Skinner J, Su Q, Johns RA (2006) New role for spinal Stargazin in alpha-amino-3-hydroxy-5-methyl-4-isoxazolepropionic acid receptormediated pain sensitization after inflammation. J Neurosci Res 84:867873. CrossRef Medline

Tao YX, Rumbaugh G, Wang GD, Petralia RS, Zhao C, Kauer FW, Tao F, Zhuo M, Wenthold RJ, Raja SN, Huganir RL, Bredt DS, Johns RA (2003) Impaired NMDA receptor-mediated postsynaptic function and blunted NMDA receptor-dependent persistent pain in mice lacking postsynaptic density-93 protein. J Neurosci 23:6703-6712. Medline

Tsankova NM, Berton O, Renthal W, Kumar A, Neve RL, Nestler EJ (2006) Sustained hippocampal chromatin regulation in a mouse model of depression and antidepressant action. Nat Neurosci 9:519-525. CrossRef Medline

Vachon-Presseau E, Martel MO, Roy M, Caron E, Albouy G, Marin MF, Plante I, Sullivan MJ, Lupien SJ, Rainville P (2013) Acute stress contributes to individual differences in pain and pain-related brain activity in healthy and chronic pain patients. J Neurosci 33:6826-6833. CrossRef Medline

Vanhoose AM, Winder DG (2003) NMDA and betal-adrenergic receptors differentially signal phosphorylation of glutamate receptor type 1 in area CA1 of hippocampus. J Neurosci 23:5827-5834. Medline

Vitale G, Arletti R, Sandrini M (2005) Acute noise stress analgesia in relation to 5-HT2 and mu-opioid receptor changes in the frontal cortex of young mice. Life Sci 77:2500-2513. CrossRef Medline

Wang S, Lim G, Zeng Q, Sung B, Ai Y, Guo G, Yang L, Mao J (2004a) Expression of central glucocorticoid receptors after peripheral nerve injury contributes to neuropathic pain behaviors in rats. J Neurosci 24: 8595-8605. CrossRef Medline

Wang W, Zhu W, Wang S, Yang D, Crow MT, Xiao RP, Cheng H (2004b) Sustained beta1-adrenergic stimulation modulates cardiac contractility by $\mathrm{Ca} 2+/$ calmodulin kinase signaling pathway. Circ Res 95:798-806. CrossRef Medline

Wilkinson MB, Dias C, Magida J, Mazei-Robison M, Lobo M, Kennedy P, Dietz D, Covington H 3rd, Russo S, Neve R, Ghose S, Tamminga C, Nestler EJ (2011) A novel role of the WNT-dishevelled-GSK3 $\beta$ signaling cascade in the mouse nucleus accumbens in a social defeat model of depression. J Neurosci 31:9084-9092. CrossRef Medline

Youn DH, Royle G, Kolaj M, Vissel B, Randić M (2008) Enhanced LTP of primary afferent neurotransmission in AMPA receptor GluR2-deficient mice. Pain 136:158-167. CrossRef Medline 